\title{
PENGARUH MOTIVASI KERJA DAN KOMPENSASI TERHADAP KINERJA KARYAWAN PADA DIVISI PRODUKSI PT. KUSUMA KAISAN SENTUL-BOGOR
}

\author{
THE EFFECT OF WORK MOTIVATION AND COMPENSATION TOWARD EMPLOYEE \\ PERFORMANCE IN PRODUCTION DIVISION OF PT. KUSUMA KAISAN SENTUL-BOGOR
}

\author{
Erni Yuningsih"); Sri Harini' ${ }^{2}$; M.Gusnul Rifky ${ }^{3)}$ \\ Program Studi Manajemen Fakultas Ekonomi Universitas Djuanda Bogor \\ erniyuningsih1970@gmail.com; sri.harini@unida.ac.id; edorifky@gmail.com
}

\begin{abstract}
This study aims to determine the effect of work motivation and compensation on the performance of PT Kusuma Kaisan simultaneously and partially. By using the Slovin technique in determining the number of samples, the questionnaire was distributed to 100 respondents. The results of validity and reliability tests show that all questions are declared valid and reliable. The results of multiple correlation analysis states that there is a strong relationship between work motivation and compensation on employee performance, the results of the coefficient of determination can be explained as $62 \%$ of employee performance is influenced by work motivation and compensation while $68 \%$ is influenced by other variables not examined in research this, such as job satisfaction, stress levels, work conditions, and job design. The F multiple regression analysis (simultaneous) states that there is a positive and significant effect simultaneously between work motivation and compensation on employee performance. The results of the $t$ test (partial) state that has a work motivation positive and significant effect on employee performance and has a compensation positive and significant effect on employee performance PT Kusuma Kaisan. Of course there needs to be an increase in employee performance with the human resources scorecard approach, providing motivation in increasing the need for relationships between employees, and providing compensation in the form of social security benefits.
\end{abstract}

Keywords: Work Motivation, Compensation, Employee Performance

\begin{abstract}
ABSTRAK
Penelitian ini bertujuan untuk mengetahui pengaruh motivasi kerja dan kompensasi terhadap kinerja karyawan PT Kusuma Kaisan secara simultan maupun parsial. Dengan menggunakan teknik slovin dalam menentukan jumlah sampel, kuesioner didistribusikan kepada 100 responden. Hasil uji validitas dan reliabilitas menunjukan bahwa seluruh butir pertanyaan dinyatakan valid dan reliabel. Hasil analisis korelasi ganda menyatakan bahwa terdapat hubungan yang kuat antara motivasi kerja dan kompensasi terhadap kinerja karyawan, hasil dari koefisien determinasi dapat dijelaskan sebesar $62 \%$ kinerja pegawai dipengaruhi oleh pelatihan kerja dan motivasi kerja sedangkan 38\% dipengaruhi oleh variabel lain yang tidak diteliti dalam penelitian ini, seperti kepuasan kerja, tingkat stres, kondisi pekerjaan, dan desain pekerjaan. Adapun analisis regresi berganda uji $\mathrm{F}$ (simultan) menyatakan bahwa terdapat pengaruh positif dan signifikan secara simultan antara motivasi kerja dan kompensasi terhadap kinerja karyawan. Hasil uji $\mathrm{t}$ (parsial) menyatakan bahwa motivasi kerja berpengaruh positif dan signifikan terhadap kinerja pegawai dan kompensasi berpengaruh positif dan signifikan terhadap kinerja karyawan PT Kusuma Kaisan. Tentunya perlu ada peningkatan kinerja karyawan dengan pendekatan human resources scorecard, pemberian motivasi dalam meningkatan kebutuhan berhubungan antar karyawan, dan pemberian kompensasi berupa tunjangan jaminan sosial.
\end{abstract}

Kata Kunci: Motivasi Kerja, Kompensasi, Kinerja. 


\section{PENDAHULUAN}

Sumber daya manusia untuk sebuah perusahaan merupakan pilar yang penting. Tidak dapat dipungkiri perkembangan sebuah perusahaan sangat dipengaruhi oleh kinerja sumber daya manusianya. Setiap perusahan tentunya memiliki keinginan kinerja sumber daya manusia yang baik dan mampu bersaing secara global. Kinerja yang baik akan tercipta dengan adanya hubungan yang harmonis dan suasana kerja yang sangat menyenangkan. Faktor yang akan mempengaruhi terciptanya kinerja yang baik menurut Handoko (2010:193) yaitu: (1) motivasi. (2) kepuasan kerja. (3) tingkat stres. (4) kondisi (5) sistem kompensasi. (6) desain pekerjaan.

Faktor motivasi tentunya dapat mempengaruhi kinerja yang diberikan sumber daya manusia terhadap perusahaan. Dorongan semangat yang timbul akibat motivasi kerja tentunya akan menciptakan hubungan yang harmonis antara karyawan dengan perusahaan. Selain itu, kompensasi merupakan faktor lain dalam meningkatkan kinerja karyawan. Balasan penganti yang diberikan kepada karyawan tentunya akan membuat suasana kerja menjadi menyenangkan atau sebaliknya, tergantung kemampuan perusahaan membayar dengan batas ketentuan yang diberlakukan oleh pemerintah. PT. Kusama Kaisan merupakan perusahaan yang bergerak dalam memproduksi hasil laut yaitu ubur-ubur.

Dalam produksinya bahan baku akan dibersihkan atau diproses oleh divisi produksi, oleh karena itu kinerja karyawannya dapat dilihat dari pencapaian hasil produksinya, berikut data hasil produksi PT. Kusama Kaisan selama 2017.

Tabel 1. Data Hasil Produksi Periode 2017

\begin{tabular}{ccccccccr}
\hline \multirow{2}{*}{ Bulan } & \multicolumn{2}{c}{ Bahan baku } & \multicolumn{2}{c}{ Target } & \multicolumn{2}{c}{ Actual } & \multicolumn{2}{c}{ Pencapaian (\%) } \\
\cline { 2 - 9 } & $\begin{array}{c}\text { Badan } \\
(\mathbf{k g})\end{array}$ & $\begin{array}{c}\text { Kaki } \\
(\mathbf{k g})\end{array}$ & $\begin{array}{c}\text { Badan } \\
(\mathbf{k g})\end{array}$ & $\begin{array}{c}\text { Kaki } \\
(\mathbf{k g})\end{array}$ & $\begin{array}{l}\text { Badan } \\
(\mathbf{k g})\end{array}$ & $\begin{array}{l}\text { Kaki } \\
(\mathbf{k g})\end{array}$ & Badan & Kaki \\
\hline Januari & 2200 & 9120 & 2090 & 8664 & 1881 & 7624 & 90 & 88 \\
Febuari & 3000 & 8660 & 2850 & 8227 & 2622 & 7157 & 92 & 87 \\
Maret & 2500 & 8700 & 2375 & 8265 & 2090 & 7769 & 88 & 94 \\
April & 2300 & 8880 & 2185 & 8436 & 2032 & 7339 & 93 & 87 \\
Mei & 2400 & 8860 & 2280 & 8417 & 2166 & 7659 & 95 & 91 \\
Juni & 2460 & 8540 & 2337 & 8113 & 2150 & 7464 & 92 & 92 \\
Juli & 2400 & 6960 & 2280 & 6612 & 2166 & 5819 & 95 & 88 \\
Agustus & 2440 & 7920 & 2318 & 7524 & 2086 & 6546 & 90 & 87 \\
September & 2420 & 8440 & 2299 & 8018 & 2207 & 7537 & 96 & 94 \\
Oktober & 2480 & 7480 & 2356 & 7106 & 2191 & 6609 & 93 & 93 \\
November & 2660 & 6580 & 2527 & 6251 & 2274 & 5751 & 90 & 92 \\
Desember & 2700 & 7860 & 2565 & 7467 & 2360 & 6646 & 92 & 89 \\
\hline Rata-rata & $\mathbf{2 4 9 7}$ & $\mathbf{8 1 6 7}$ & $\mathbf{2 3 7 2}$ & $\mathbf{7 7 5 8}$ & $\mathbf{2 1 8 5}$ & $\mathbf{6 9 9 3}$ & $\mathbf{9 2}$ & $\mathbf{9 0}$ \\
\hline
\end{tabular}

Sumber: PT. Kusuma Kaisan 2018 
Berdasarkan Tabel 1 produk ubur-ubur yang dikelola dibagi menjadi dua bagian yaitu bagian badan dan kaki. Dalam menentukan target yang ingin dicapai, perusahaan akan mengambil $95 \%$ bahan baku akan dikelola atau batas toleransi atas kerusakan dari produk yang dikelola sebesar 5\% yang dikelola. Perusahaan menetapkan minimal pencapaian hasil produksi sebesar $95 \%$ dari target yang telah ditetapkan oleh perusahaan. Pada tahun 2017 rata-rata pencapaian produksi badan dan kaki mendapatkan $92 \%$ dan $90 \%$ dari target. Faktorfaktor yang mempengaruhi kinerja karyawan antara lain motivasi dan kompensasi. Berdasarkan data yang ada, mengindikasikan motivasi karyawan PT. Kusuma Kaisan mengalami penurunan ditunjukan oleh tingkat absensi karyawan. Berikut data absensi divisi produksi PT. Kusuma Kaisan.

Tabel 2. Data Absensi Karyawan PT. Kusuma Kaisan Periode 2017

\begin{tabular}{|c|c|c|c|c|c|c|}
\hline Bulan & $\begin{array}{c}\text { Jumlah } \\
\text { Karyawan }\end{array}$ & $\begin{array}{l}\text { Total } \\
\text { Hari } \\
\text { Kerja }\end{array}$ & $\begin{array}{c}\text { Total } \\
\text { Kehadiran } \\
\text { Seharusnya }\end{array}$ & $\begin{array}{c}\text { Absensi } \\
\text { Karyawan }\end{array}$ & $\begin{array}{c}\text { Total } \\
\text { Kehadiran }\end{array}$ & $\begin{array}{c}\text { Persentase } \\
\text { Ketidakhadiran } \\
\text { Karyawan } \\
(\%)\end{array}$ \\
\hline Januari & 120 & 25 & 3000 & 111 & 2889 & 3.70 \\
\hline Febuari & 120 & 24 & 2880 & 89 & 2791 & 3.09 \\
\hline Maret & 120 & 26 & 3120 & 124 & 2996 & 3.97 \\
\hline April & 120 & 23 & 2760 & 115 & 2645 & 4.17 \\
\hline Mei & 120 & 20 & 2400 & 100 & 2300 & 4.17 \\
\hline Juni & 120 & 18 & 2160 & 99 & 2061 & 4.58 \\
\hline Juli & 120 & 18 & 2160 & 37 & 2123 & 1.71 \\
\hline Agustus & 120 & 26 & 3120 & 86 & 3034 & 2.76 \\
\hline Septembe & 120 & 24 & 2880 & 79 & 2801 & 2.74 \\
\hline \multicolumn{7}{|l|}{$\mathrm{r}$} \\
\hline Oktober & 120 & 26 & 3000 & 87 & 2913 & 2.9 \\
\hline November & 120 & 26 & 3000 & 78 & 2922 & 2.6 \\
\hline \multirow[t]{2}{*}{ Desember } & 120 & 23 & 2640 & 87 & 2553 & 3.3 \\
\hline & Rata-rata & 23 & 2760 & 91 & 2669 & 3.31 \\
\hline
\end{tabular}

Sumber: PT. Kusuma Kaisan 2018

Berdasarkan Tabel 2 dapat disimpulkan bahwa rata-rata persentase ketidakhadiran karyawan mencapai $3.31 \%$, dapat dikatakan tinggi berdassarkan batas toleransi yang diterapkan oleh perusahaan untuk ketidakhadiran sebesar $2.5 \%$. Sejalan dengan Sanjaya (2015:45) rata-rata tingkat absensi sejumlah $2 \%$ hingga $3 \%$ dalam satu bulan masih dapat dikategorikan baik, namun jika lebih dari 3\% maka dikategorikan organisasi tersebut memiliki kedisiplinan yang kurang baik. Hal ini disebabkan oleh para karyawan memiliki pekerjaan sampingan di luar jam kerjanya akibat gairah dan semangat kerja yang rendah serta tidak puas dengan penghasilannya. Dapat dilihat adanya indikasi yang rendah terhadap motivasi karyawan akibat gairah dan semangat kerja yang rendah. Selain itu faktor kompensasi tentunya dapat mempengaruhi kinerja. Salah satu bentuk kompensasi dasar ialah gaji. Gaji merupakan uang tunai yang diterima oleh karyawan setiap periode tertentu. Berikut data kenaikan gaji karyawan PT. Kusama Kaisan selama 2010 sampai dengan 2017. 


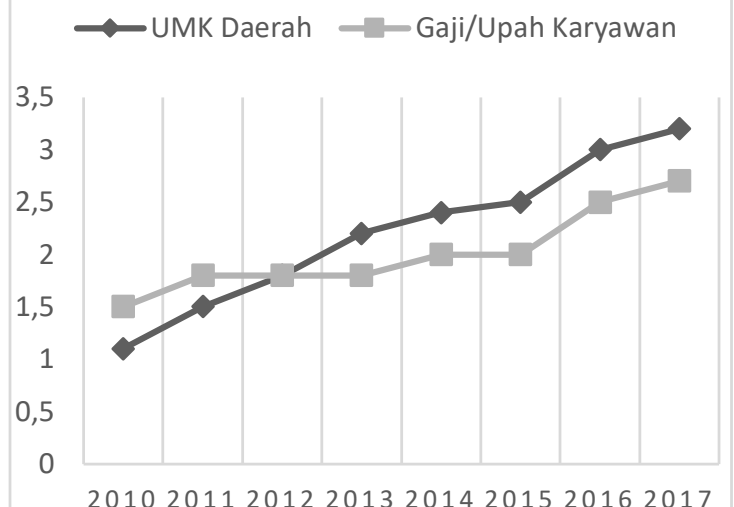

Sumber: PT. Kusuma Kaisan 2018

Gambar 1. Grafik Gaji/Upah PT. Kusuma Kaisan Periode 2010 sampai dengan 2017

Berdasarkan Gambar 1 menunjukan bahwa pada tahun 2010 dan 2011 karyawan PT. Kusuma Kaisan menerima gaji atau upah 40\% lebih tinggi pada upah minimum daerah. Pada tahun 2012 karyawan PT. Kusuma Kaisan menerima gaji atau upah yang setara upah minimum daerah, namun pada 2013 sampai dengan 2017 karyawan PT. Kusuma Kaisan menerima $85 \%$ dari upah minimum daerah. Berdasarkan UU Ketenagakerjaan No. 13 Tahun 2003 pasal 94 berisi tentang ketetapan upah minum minimal $75 \%$ dari ketetapan peraturan daerah. Perusahaan masih dalam koridor ketetapan UU Ketenagakerjaan tentang pemberian upah kepada karyawan. Berdasarkan observasi yang dilakukan di PT. Kusuma Kaisan, perusahaan untuk saat ini hanya memberikan kompensasi berbentuk gaji atau upah dan Tunjangan Hari Raya (THR) yang diterima oleh karyawan.

Berdasarkan pemberian upah yang diberikan perusahaan kepada karyawan sebesar $85 \%$ dari upah minimum daerah. Perusahaan harusnya mampu memberikan kompensasi bentuk lain. Berikut di bawah ini data kompensasi yang diberikan oleh PT. Kusuma Kaisan.

Berdasarkan Tabel 3 dapat dilihat bahwa pemberian kompensasi PT. Kusuma Kaisan tempat bekerja. Untuk penilaian kinerja menggunakan sistem pengukuran sumber daya manusia melalui pendekatan Human Resources
Tabel 3. Data Kompensasi

PT. Kusuma Kaisan periode 2017

\begin{tabular}{|c|c|c|c|c|c|}
\hline \multirow{3}{*}{ Divisi } & \multicolumn{5}{|c|}{ Kompensasi } \\
\hline & \multirow{2}{*}{$\begin{array}{l}\text { Gaji / } \\
\text { upah }\end{array}$} & \multicolumn{3}{|c|}{ Tunjangan } & \multirow[t]{2}{*}{ Insentif } \\
\hline & & Jamsostek & Transport & THR & \\
\hline Staft & $\checkmark$ & - & - & $\checkmark$ & - \\
\hline Teniksi & $\checkmark$ & - & - & $\checkmark$ & - \\
\hline Produksi & $\checkmark$ & - & - & $\checkmark$ & - \\
\hline Gudang & $\checkmark$ & - & - & $\checkmark$ & - \\
\hline
\end{tabular}

Sumber: PT. Kusuma Kaisan 2018

meliputi gaji atau upah dan tunjangan hari raya, sedangkan jamsostek, transport, dan instensif tidak didapatkan oleh karyawan PT. Kusuma Kaisan. Hal ini sungguh bertentangan dengan UU Jamsostek No. 3 Tahun 1992 program Jamsostek dan PP No. 14 Tahun 1993 tentang Penyelenggaraan Jamsostek. Pemberian motivasi dan kompensasi menjadi faktor penting yang mempengaruhi pencapaian target suatu perusahaan. Pemberian motivasi dan kompensasi tentu berdampak terhadap kinerja karyawan. Sedangkan kinerja karyawan akan berdampak pada pencapaian perusahaan yang ditargetkan. Kinerja karyawan berdampak terhadap tujuan perusahaan, oleh karena itu pihak manajemen PT. Kusuma Kaisan sepatutnya memperhatikan faktor-faktor yang mempengaruhi kinerja karyawan yaitu motivasi dan kompensasi.

\section{MATERI DAN METODE}

\section{Kinerja}

Kinerja merupakan hasil kerja secara individual atau kolektif dalam menjalankan tugas yang diberikan (Mangkunegara, 2011 ; Dharma, 2013; dan Syamsir, 2013). Apabila dihubungkan dengan proses pekerjaan, menunjukkan kemampuan seorang karyawan dalam menjalankan tugasnya di kantor atau

Scorecard, yaitu mengidentifikasi kompempetensi, pengukuran High Performance Work System (HPWS), mengukur 
Human Resources Scorecard System Alignment, Human Resources Scorecard Efficiency, Human Resources Scorecard Deliverable (Dharma, 2013).

Tujuan Peningkatan Kinerja: antara lain peningkatan kinerja, penyesuaian kompensasi, keputusan penempatan, pelatihan dan kebutuhan pengembangan. perencanaan dan pengembangan karir, kekurangan proses kepegawaian, ketidakakuratan informasi dan kesalahan desain pekerjaan, kesempatan kerja yang setara, umpan balik, dan tantangan eksternal (Werther, 2011).

Berikut adalah indikator dari kinerja itu sendiri;

(1) kualitas merupakan ukuran seberapa baik karyawan dalam mengerjakan pekerjaannya,

(2) kuantitas merupakan ukuran seberapa lama karyawan dalam mengerjakan pekerjaannya,

(3) pelaksanaan tugas merupakan seberapa jauh karyawan mampu melakukan pekerjaannya dengan akurat atau tidak ada kesalahan, dan

(4) tanggung jawab adalah kesadaran akan kewajiban karyawan untuk melaksanakan pekerjaan yang diberikan perusahaan (Mangkunegara, 2011).

Dalam penelitian ini merujukan bahwa kinerja dipengaruhi oleh motivasi dan kompensasi secara silmultan dengan didukung oleh penelitian sebelumnya oleh Danish (2015), Pearce dkk (2017) dan Wenno (2017).

\section{Motivasi Kerja}

Motivasi merupakan daya gerak atau kejutan semangat dalam kondisi seseorang melakukan, bersikap dan bertingkah laku untuk mencapai tujuan yang diinginkan. (Syahyuti, 2010; Suwanto, 2011; dan Hasibuan, 2014).
Motivasi bisa menjadi positif dan negatif tergantung kondisi perasaan terhadap pekerjaannya bisa membuat tertarik atau membosankan. Ada beberapa teori tentang motivasi yaitu; Teori kebutuhan dari Maslow meliputi kebutuhan fisiologis, keamanan dan keselamatan kerja, sosial, penghargaan serta aktualisasi diri . Teori motivasi kesehatan dari Frederick Herzberg meliputi kebutuhan psikologis dan kebutuhan akan pemeliharaan. Teori motivasi berprestasi McClelland meliputi kebutuhan untuk berprestasi, kebutuhan untuk berafiliasi dan kebutuhan untuk kekuasaan. Teori kebutuhan dari Alderfer meliputi kebutuhan keberadaan, berhubungan, dan pertumbuhan. Teori X dan Y dari Mcgregor menyatakan bahwa manusia memilki kedua sisi yang berlawanan, mereka tidak suka untuk berada dalam tekanan sedangkan dalam hakekatnya manusia memiliki hasrat dalam berkembang. Dan teori harapan dari Vroom meliputi harapan dan nilai (Hasibuan, 2014).

Berikut adalah indikator dari motivasi; (1) dorongan mencapai tujuan artinya keinginan yang kuat untuk mencapai kinerja yang maksimal, yang nantinya akan berpengaruh terhadap tujuan dari suatu perusahaan atau instansi. (2) semangat kerja artinya kesenangan yang mendorong seseorang untuk bekerja lebih giat dan lebih baik serta konsekuen dalam mencapai tujuan yang ditetapkan oleh perusahaan atau instansi. (3) inisiatif diartikan sebagai kekuatan atau kemampuan seseorang karyawan atau pegawai untuk memulai atau meneruskan suatu pekerjaan dengan penuh energi tanpa ada dorongan dari orang lain atau atas kehendak sendiri. (4) kreatifitas adalah kemampuan seseorang pegawai atau karyawan untuk menemukan suatu yang baru (Syahyuti, 2010).

Dalam penelitian ini merujukan bahwa kinerja dipengaruhi oleh motivasi dengan didukung oleh penelitian sebelumnya oleh Springer (2016), Azar (2018), dan Azeem (2018) 


\section{Kompensasi}

Kompensasi merupakan gambaran ganti rugi yang diberikan oleh penerima jasa atau tenaga yang dihasilkan oleh tenaga kerja. Penganti dari kontribusi jasa yang diberikan tenaga kerja oleh pihak yang memperoleh manfaat dari pelaksaanan tugas yang dilaksanakan. (Kadarisman, 2010; Siswandoko, 2011; dan Sagala, 2014) Kompensasi itu sendiri terbagi menjadi dua bentuk antara lain seperti secara materiel yang dapat dirassakan secara langsung (gaji), dan non materiel yang tidak dirasakan secara langsung (tunjangan) (Yani, 2012). Kompensasi dapat dipengaruhi oleh kemampuan perusahaan, permintaan tenaga kerja, regurasi dari pemerintah, kondisi perekonomian dan tingkat pendidikan. (Mangkunegara, 2011 dan Hasibuan, 2014).

Pemerintah selaku regulator dalam pengelolaan sistem kompensasi tertuang pada UU ketenagakerjaan dan UU jaminan sosial tenaga kerja. Berikut adalah indikator dari kompensasi;

(1) kewajaran/ keadilan internal berarti setiap jabatan/posisi dan pekerjaan individu dihargai oleh organisasi/perusahaan dengan perbandingan yang rasional, dari yang terendah sampai dengan yang tertinggi.
(2) kewajaran/keadilan eksternal berarti kompensasi dilakukan dengan memperhatikan nilai pasar tenaga kerja di luar organisasi/perusahaan, yang mampu bersaing dengan kompensasi yang diberikan oleh organisasi/perusahaan lain yang sejenis (pesaing). kewajaran/keadilan individual berarti setiap individu pegawai merasakan kompensasinya wajar dibandingkan dengan pegawai yang lain dalam pekerjaan yang memiliki kesamaan (Kadarisman, 2010).

Dalam penelitian ini merujukan bahwa kinerja dipengaruhi oleh kompensasi dengan didukung oleh penelitian sebelumnya oleh Harry dan Luis (2016), Wekesa (2018), dan Barry dan Geogre (2019).

\section{Hipotesis Penelitian}

H1: Pengaruh Motivasi Kerja dan Kompensasi Terhadap Kinerja Pegawai.

H2: Pengaruh Motivasi Kerja Terhadap Kinerja Karyawan.

H3: Pengaruh Kompensasi Terhadap Kinerja Karyawan. 
PENGARUH MOTIVASI KERJA DAN KOMPENSASI TERHADAP KINERJA KARYAWAN PT. KUSUMA KAISAN

\section{Latar Belakang}

Setiap perusahaan tentu membutuhkan sumber daya manusia yang berkualitas, yang mampu bekerja dengan sebaik mungkin dengan hasil yang optimal. Maka untuk mengwujudkannya perusahaan perlu memperhatikan kinerja karyawanya. Faktor yang mempengaruhi kinerja karyawan adalah pemberian motivasi dan kompensasi agar mampu mencapai target yang optimal.

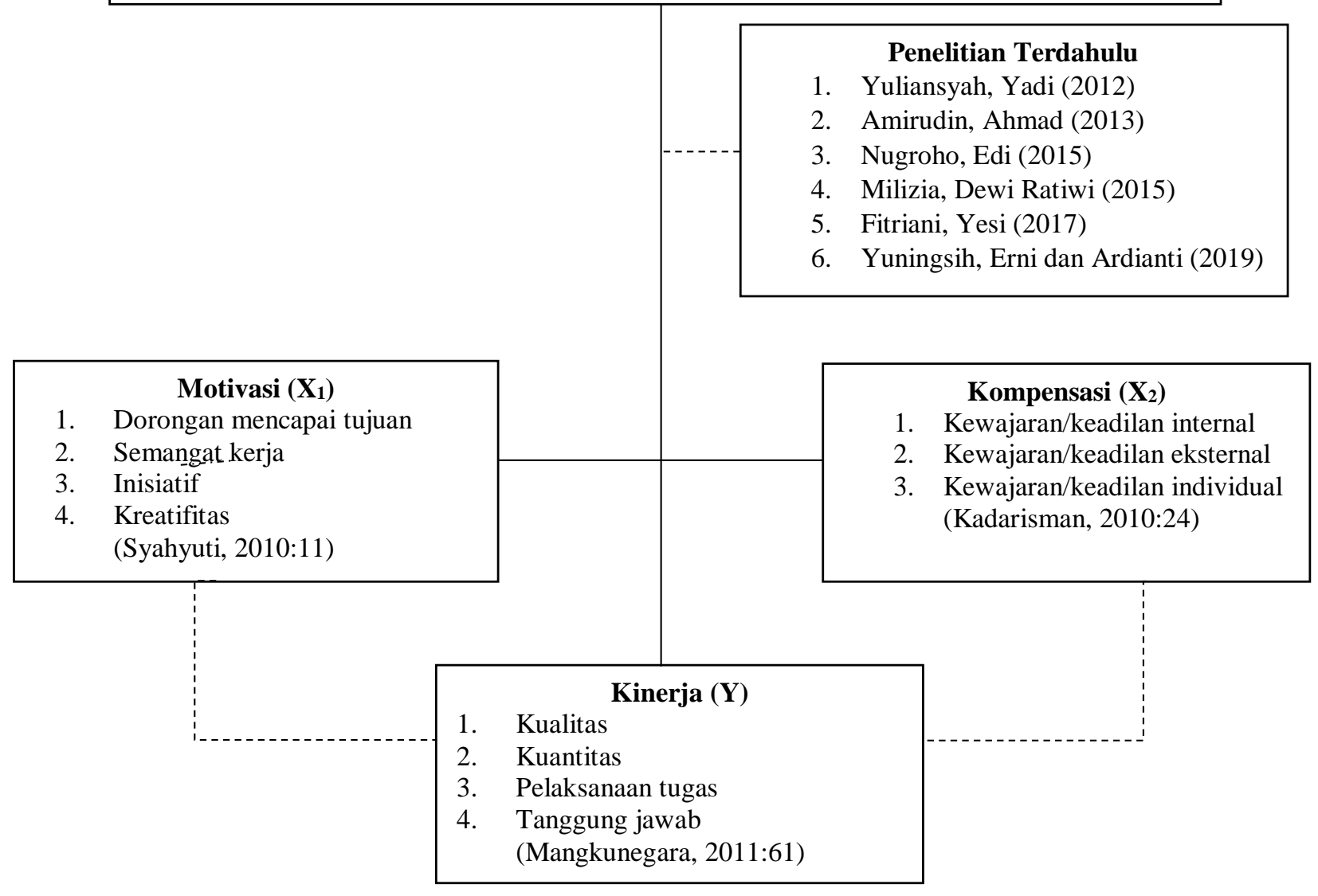

Sumber: Diolah penulis, 2018

\section{Gambar 2. Kerangka Pemikiran}

\section{Desain Penelitian}

Model penelitian yang dilakukan oleh peneliti ini menggunakan metode deskriptif kuantitatif. Dengan objek penelitiannya yaitu karyawan PT. Kusuma Kaisan mengenai pengaruh motivasi kerja dan kompensasi terhadap kinerja karyawan. Dalam penelitian ini memberikan suatu gambaran data yang dianalisis secara akurat, sistematis, statistik, dan jelas. Analisis kuantitatif didasarkan pada analisis variabel-variabel yang dapat dijelaskan secara kuantitas (dapat diukur) dengan rumusrumus atau alat analisa pasti.

Metode kuantitatif adalah metode yang digunakan untuk penyajian hasil penelitian dalam bentuk angka-angka dan analisisnya 
menggunakan statistik. pendekatannya melalui kuantitatif dan verifikatif menjelaskan dan mendeskripsikan variabel-variabel dengan data berupa angka kemudian menjelaskan hubungan kedua variabel melalui uji hipotesis serta pembuktian, untuk menguji hipotesis hasil penelitian deskriptif dengan perhitungan statistika, sehingga didapat hasil penelitian yang menujukan hipotesis ditolak atau diterima. (Sugiyono, 2014)

\section{Tabel 4. Definisi Operasional Variabel}

\begin{tabular}{lll}
\hline \multicolumn{1}{c}{ Variabel } & Indikator & Item \\
\hline Kinerja (Y) & 1. Kualitas & $1-4$ \\
& 2. Kuantitas & $5-6$ \\
& 3. Pelaksanaan Tugas & $7-9$ \\
& 4. Tanggung Jawab & $10-11$ \\
& (Mangkunegara, 2011:193) & \\
Motivasi & 1. Dorongan mencapai & $1-3$ \\
(X1) & $\quad$ tujuan & $4-6$ \\
& 2. Semangat kerja & $7-8$ \\
& 3. Inisiatif & $9-10$ \\
& 4. Kreatifitas & \\
Kompensasi & (Syahyuti, 2010:7) & $1-4$ \\
& 1. Kewajaran/ keadilan & $5-7$ \\
& 2. Kewajaran/keadilan & \\
& $\quad$ Eksternal. & $8-10$ \\
& 3. Kewajaran/keadilan & \\
& $\quad$ Individual. & \\
& .( Kadarisman, 2010:4) & \\
\hline
\end{tabular}

Sumber: Diolah penulis, 2018

\section{Metode Pengujian Data}

Untuk penelitian dengan menggunakan data primer yang menggunakan kuisioner penelitian, sebelumnya perlu diuji dahulu data yang diperoleh, dengan uji validitas (keabsahan) dan reliabilitas (dapat dipercaya) dari instrumen data penelitian, sehinggga diperoleh hasil, apakah kuisioner penelitian tersebut layak atau tidak untuk dijadikan data penelitian.

Uji validitas untuk mengukur sahih atau kebenaran setiap butir pernyataan dalam kuesioner yang diteliti. Mengukur tingkat validitas atau tidaknya suatu kuesioner dapat menggunakan nilai pearson, dimana persyaratan uji validitas menggunakan tabel $\mathrm{r}$ $\left(\mathrm{r}_{\text {tabel }}<\mathrm{r}_{\text {hitung }}\right)$ maka dapat dinyatakan valid.
Hasil uji validitas keseluruhan kuesioner dalam penelitian dikatakan valid karena tidak ada nilai dibawah tabel $r$ yang ditetapkan.

Uji Reliabilitas digunakan untuk apakah data yang digunakan dalam penelitian handal dan abash terhadap bagian indikator dari variabel atau konstruk sehingga data yang diperoleh bersipat konsisten. Untuk mengetahui hasil pengujian didapat dengan membandingkan nilai koefisien alpha jika hasil dari pengolahan data lebih dari atau sama dengan 0.6 maka data dapat dikatakan reliabel dan jika kurang dari 0.6 maka data tidak reliabel. Hasilnya dalam penelitian ini menunjukkan bahwa semua variabel mempunyai nilai diatas 0,60 sehingga berarti bahwa kuesioner yang digunakan dalam penelitian ini merupakan kuesioner yang reliabel.

Uji Asumsi klasik digunakan sebagai alat untuk mengetahui data yang dipakai dalam penelitian tidak memiliki masalah-masalah asumsi klasik seperti normalitas, multikolinearitas, dan heteroskedastisitas. Hasil uji asumsi klasik menyimpulkan bahwa tidak ada masalah normalitas, multikolinearitas, dan heteroskedastisitas dan model regresi layak dipakai sebagai prediksi.

\section{HASIL DAN PEMBAHASAN Karakteristik Responden}

Karyawan PT. Kusuma Kaisan divisi produksi yang terbanyak adalah berjenis kelamin perempuan sebesar 80 orang karyawan (80\%), dan laki-laki sebesar 20 orang karyawan (20\%). Hal ini menunjukkan bahwa dalam pekerjaan yang dilakukan didominasi oleh perempuan karena pekerjaan yang dilakukan berupa mencuci atau membersihkan ubur-ubur dari pasir, garam dan lendirnya yang secara umum dilakukan oleh para perempuan. Rata-rata berusia di atas 30 tahun namun di bawah 40 tahun. Hal ini dasari dengan dibangunnya pabrik di daerah Sentul pada tahun 2009 dengan merekrut dalam skala besar 
dan rata-rata usia karyawan pada saat itu berumur 25 tahun.

Berpendidikan SMP sebesar 79 orang karyawan (79\%) dan berpendidikan SMA/SMK sebesar 21 orang karyawan (21\%).Pekerjaan yang ada di divisi produksi tidak terlalu memerlukan pengetahuan atau berwawasan secara luas, dengan kata lain mampu dilakukan secara umun. Rata-rata masa kerjanya 5-7 tahun. Karena pada tahun 2009 terjadi recruitment dalam skala besar untuk menambah kapasitas produksi. Namun dalam kurun waktu 2009-2011 terjadi turnover karyawan yang tinggi. Sedangkan untuk karyawan dengan masa kerja $>8$ tahun dibawa secara langsung dari Cilacap.

Tanggapan Karyawan Terhadap Kinerja, Motivasi dan Kompensasi

Untuk mengetahui bagaimana pengaruh motivasi dan kompensasi terhadap kinerja karyawan PT. Kusuma Kaisan. Maka dalam penelitian ini menggunakan kuisioner untuk mengukurnya.

Berikut adalah rekapitulasi tanggapan karyawan terhadap kinerja, motivasi dan kompensasi:

\section{Tabel 5. Rekapitulasi Jawaban Variabel Kinerja}

\begin{tabular}{|c|c|c|c|}
\hline Indikator & $\begin{array}{l}\text { Penilaian } \\
\text { Kriteria }\end{array}$ & Kategori & Interpretasi \\
\hline Kualitas & 3.93 & Baik & $\begin{array}{l}\text { Kualitas produk yang dihasilkan } \\
\text { karyawan termasuk berkualitas yang } \\
\text { super. }\end{array}$ \\
\hline Kuantitas & 4.18 & Baik & $\begin{array}{l}\text { Pengelolaan waktu kerja oleh } \\
\text { karyawan tergolong efisien }\end{array}$ \\
\hline Pelaksanaan tugas & 4.40 & $\begin{array}{l}\text { Sangat } \\
\text { Baik }\end{array}$ & $\begin{array}{l}\text { Kemampuan karyawan dalam } \\
\text { menjalankan pelaksaan tugas atau } \\
\text { pekerjaan di perusahaan tergolong } \\
\text { sangat efektif }\end{array}$ \\
\hline Tanggung jawab & 4.00 & Baik & $\begin{array}{l}\text { Tugas atau pekerjaan yang dibebankan } \\
\text { kepada karyawan dilaksanakan sesuai } \\
\text { ketentuan berjalan lancar }\end{array}$ \\
\hline Rata-rata penilaian & 4.13 & Baik & $\begin{array}{l}\text { Kinerja karyawan berdasarkan } \\
\text { kualitas, kuantitas, pelaksanaan } \\
\text { tugas, dan tanggung jawab di } \\
\text { perusahaan tergolong baik }\end{array}$ \\
\hline
\end{tabular}

Sumber : Data SPSS Diolah.

Berdasarkan rentang skor rata-rata berada pada interval 3,41 - 4,20 yang berarti masuk dalam klasifikasi penilaian baik, hal ini berarti kinerja karyawan dalam perusahaan tergolong baik. Adapun kondisi di atas dapat dijelaskan sebagai berikut :

1. Indikator pelaksanaan tugas mendapatan kategori sangat baik dengan nilai tertinggi pada variabel kinerja. Hal ini tentunya perlu dipertahankan oleh pihak manajemen perusahaan.

2. Indikator kualitas mendapatan kategori sangat baik dengan nilai terendah pada variabel kinerja. Hal ini tentunya perlu ditingkatan oleh pihak manajemen perusahaan. 
Tabel 6. Rekapitulasi Jawaban Variabel Motivasi

\begin{tabular}{|c|c|c|c|}
\hline Indikator & $\begin{array}{l}\text { Penilaian } \\
\text { Kriteria }\end{array}$ & Kategori & Interpretasi \\
\hline $\begin{array}{l}\text { Dorongan mencapai } \\
\text { tujuan }\end{array}$ & 4.00 & Tinggi & $\begin{array}{l}\text { Dorongan didalam diri karyawan untuk } \\
\text { bekerja di perusahaan tergolong tinggi }\end{array}$ \\
\hline Samangat kerja & 3.98 & Tinggi & $\begin{array}{l}\text { Semangat kerja karyawan untuk bekerja } \\
\text { di perusahaan tergolong tinggi }\end{array}$ \\
\hline Inisiatif & 3.73 & Tinggi & $\begin{array}{l}\text { Inisiatif karyawan dalam pekerjaan di } \\
\text { perusahaan tergolong tinggi }\end{array}$ \\
\hline Kreatifitas & 4.10 & Tinggi & $\begin{array}{l}\text { Penyerapan kreatifitas karyawan di } \\
\text { perusahaan tergolong tinggi }\end{array}$ \\
\hline Rata-rata penilaian & 3.95 & Tinggi & $\begin{array}{l}\text { Motivasi karyawan berdasarkan } \\
\text { dorongan mencapai tujuan, semangat } \\
\text { kerja, inisiatif, dan tanggung jawab } \\
\text { di perusahaan tergolong tinggi }\end{array}$ \\
\hline
\end{tabular}

Sumber : Data SPSS Diolah Peneliti

Berdasarkan rentang skor rata-rata berada pada interval 3,41 - 4,20 yang berarti masuk dalam klasifikasi penilaian baik, hal ini berarti motivasi yang diberikan kepada karyawan dalam perusahaan tergolong tinggi.

Adapun kondisi di atas dapat dijelaskan sebagai berikut :

1. Indikator kreatifitas mendapatan kategori tinggi dengan nilai tertinggi pada variabel motivasi. Hal ini tentunya perlu dipertahankan oleh pihak manajemen perusahaan.

2. Indikator inisiatif mendapatan kategori tinggi dengan nilai terendah pada variabel motivasi. Hal ini tentunya perlu ditingkatan oleh pihak manajemen perusahaan

Tabel 7. Rekapitulasi Jawaban Variabel Kompensasi

\begin{tabular}{lccl}
\hline Indikator & Penilaian Kriteria & Kategori & Interpretasi \\
\hline $\begin{array}{l}\text { Kewajaran/ } \\
\text { keadilan internal }\end{array}$ & 3.75 & Tinggi & $\begin{array}{l}\text { Kisaran pemberian kompensasi } \\
\text { berdasarkan kewajaran/keadilan internal } \\
\text { tergolong wajar }\end{array}$ \\
$\begin{array}{l}\text { Kewajaran/ } \\
\text { keadilan eksternall }\end{array}$ & 3.93 & Tinggi & $\begin{array}{l}\text { Kisaran pemberian kompensasi } \\
\text { berdasarkan kewajaran/keadilan } \\
\text { eksternal tergolong wajar }\end{array}$ \\
$\begin{array}{l}\text { Kewajaran/ } \\
\text { keadilan individual }\end{array}$ & 3.98 & Tinggi & $\begin{array}{l}\text { Kisaran pemberian kompensasi } \\
\text { berdasarkan kewajaran/keadilan } \\
\text { individual tergolong wajar }\end{array}$ \\
\hline & & Tinggi & $\begin{array}{l}\text { Kompensasi berdasarkan } \\
\text { kewajaran/keadilan internal, } \\
\text { eksternal, dan individual di } \\
\text { perusahaan tergolong wajar }\end{array}$ \\
\hline Rata-rata penilaian & $\mathbf{3 . 8 9}$ & &
\end{tabular}

Sumber : Data SPSS Diolah Peneliti

Berdasarkan rentang skor rata-rata berada pada interval 3,41 - 4,20 yang berarti masuk dalam klasifikasi penilaian baik, hal ini berarti kompensasi yang diberikan kepada karyawan dalam perusahaan tergolong tinggi.

Adapun kondisi di atas dapat dijelaskan sebagai berikut :
1. Indikator kewajaran/ keadilan individual mendapatan kategori tinggi dengan nilai tertinggi pada variabel kompensasi. Hal ini tentunya perlu dipertahankan oleh pihak manajemen perusahaan.

2. Indikator kewajaran/ keadilan internal mendapatan kategori terendah dengan nilai 
terendah pada variabel kompensasi. Hal ini tentunya perlu ditingkatan oleh pihak manajemen perusahaan.

\section{Analisis Regresi Berganda}

Analisis regresi berganda untuk mengetahui apakah ada pengaruh yang signifikan atau tidak dua atau lebih variabel bebas terhadap variabel terikat. Hasil analisis regresi diperoleh persamaan regresi sebagai berikut:

$$
\mathrm{Y}=2.567+0.602 x_{1}+0.494 x_{2}+\varepsilon
$$

Persamaan tersebut berarti bahwa koefisien $\mathrm{X}_{1}$ nilai 0.602 artinya motivasi kerja memiliki pengaruh yang positif terhadap kinerja. Nilai $\mathrm{X}_{2} 0.494$ artinya kompensasi memiliki pengaruh positif terhadap kinerja.

\section{Analisis Korelasi Ganda}

Hasil Korelasi Ganda menunjukan koefisien korelasi R sebesar 0.788 termasuk kategori kuat. Hal ini menunjukan bahwa hubungan antara variabel motivasi kerja $\left(\mathrm{X}_{1}\right)$ dan kompensasi $\left(\mathrm{X}_{2}\right)$ terhadap kinerja karyawan (Y) memiliki hubungan yang kuat artinya bahwa semakin tinggi motivasi kerja dan semakin tinggi kompensasi kerja maka kinerja pegawai akan semakin meningkat.

\section{Analisis Koefisien Determinasi $\left(\mathbf{R}^{\mathbf{2}}\right)$}

Hasil analisis koefisien determinasi $\left(\mathrm{R}^{2}\right)$ menunjukkan angka $R$ Square 0.62 atau $62 \%$ yakni menunjukan bahwa persentase sumbangan pegaruh variabel motivasi kerja $\left(\mathrm{X}_{1}\right)$ dan kompensasi $\left(\mathrm{X}_{2}\right)$ terhadap kinerja pegawai (Y) sebesar $62 \%$ sedangkan sisanya $38 \%$ dipengaruhi oleh faktor lain.

\section{Pengujian Hipotesis}

\section{Uji F}

Berdasarkan hasil perhitungan uji $\mathrm{F}$, dapat dilihat bahwa nilai Fhitung sebesar 79.199 dengan $\mathrm{f}_{\text {tabel }}=3.09$ taraf $5 \%$ maka berarti $F_{\text {hitung }}>\mathrm{ft}_{\text {abel }}$. Hasil $\rho=0,000<0,05$, maka Ho ditolak dan Ha diterima. Pada hasil uji F dapat ditarik kesimpulan bahwa variabel motivasi dan kompensasi berpengaruh positif dan signifikan secara simultan terhadap kinerja.

2. Uji t

Hasil uji hipotesis motivasi terhadap kinerja dari hasil perhitungan yang diperoleh thitung sebesar 4.956 lebih besar dari tabel 1.660 dengan signifikansi sebesar 0,000 lebih kecil dari taraf signifikansi 0.05. Berarti menunjukkan bahwa motivasi berpengaruh positif dan signifikan terhadap kinerja pegawai. Dan uji hipotesis kompensasi terhadap kinerja dari hasil perhitungan yang diperoleh $t_{\text {hitung }}$ untuk sebesar 4.617 lebih besar dari $t_{\text {tabel }}$ 1.660 dengan signifikansi sebesar 0.000 lebih kecil dari taraf signifikansi 0.05 . Berarti bahwa kompensasi berpengaruh positif dan signifikan terhadap kinerja pegawai.

\section{KESIMPULAN DAN IMPLIKASI}

Berdasarkan uraian pembahasan di atas, maka kesimpulan dan implikasinya adalah sebagai berikut:

1. PT. Kusuma Kaisan perlu meningkatkan kinerja karyawannya ini dapat dilihat dari kualitas yang dihasilkan karyawan belum maksimal. Tentunya kualitas produk yang dihasilkan akan berpengaruh terhadap propit dan nama perushaan. Perlu adanya evaluasi dalam hal ini dengan pendekatan Human Resources Scorecard.

2. PT. Kusuma Kaisan perlu meningkatkan motivasi kerja terhadap karyawan agar karyawan merasa dihargai di tempat kerja. Hal mendorong rasa semangat kerja, serta peningkatan terhadap inisiatif terhadap pekerjaan agar pekerjaan tidak tergantung individu tertentu. Salah satu caranya dengan meningkatan kebutuhan berhubungan (Relatedness needs) antar karyawan.

3. PT. Kusuma Kaisan harus meningkatan kewajaran/keadilan internal dalam pemberlakuan kompensasi menambahkan kompensasi berupa tunjangan jaminan 
sosial (Jamsostek) yang merupakan hak setiap tenaga kerja yang diatur dalam UU Jamsostek No. 3 Tahun 1992 program Jamsostek (Jaminan Sosial Tenaga Kerja) dengan adanya jamsostek untuk pegawai dapat meningkatan rasa kepuasan dari timbal balik yang diberikan sehingga dapat meningkatkan kinerja.

4. Saran untuk penelitian lanjutan, penelitian ini dapat dilakukan kembali dengan variabel lainnya yang mempengaruhi seperti kepuasan kerja, tingkat stres, kondisi pekerjaan, dan desain pekerjaan. Serta dimanfaatkan sebagai bahan rujukan dalam melakukan penelitian yang berkaitan dengan motivasi kerja dan kompensasi.

\section{UCAPAN TERIMA KASIH}

Ucapan terima kasih kepada PT.

Kusuma Kaisan.

\section{DAFTAR PUSTAKA}

Azar, M. (2018). The Effect of Work Motivation on Employees' Job Performance (Case Study: Employees of Isfahan Islamic Revolution Housing Foundation). International Journal of Academic Research in Business and Social Sciences. Islamic Azad University Dehaghan Branch. ISSN: 2222-6990. Vol. 3, No. 9. Hal 39-51

Azeem, M. (2018). Effect of Work Motivation on Job Satisfaction in Mobile Telecommunication Service Organizations of Pakistan. International Journal of Business and Management. Ali Jinnah University. ISSN: 2422-9690. Vol. 5, No. 11. Hal. 144-158

Barry, G. and George, T. (2019). Organizational Differences in Managerial Compensation and Financial Performance. Academy of Management Journal. eISSN 10.54585/251400. Vol. 33, No. 4 Hal.125-137
Danish, R. (2015). Impact of Reward and Recognition on Job Satisfaction and Motivation: An Empirical Study from Pakistan. International Journal of Business and Management. University of the Punjab. eISSN: 15571211- ISSN: 01492063. Vol. 5, No. 2. Hal. 158-169

Dharma, S. (2013). Manajemen Kinerja. Edisi ketiga. Pustaka Pelajar, Yogyakarta.

Disnaker. RI. (2015). Undang-Undang Jamsostek No. 3 Tahun 1992. Departemen Ketenagakerjaan. Jakarta .(2015).

Undang-Undang

Ketenagakerjaan No. 13 Tahun 2003. Departemen Ketenagakerjaan. Jakarta

Ghozali, I. (2013). Aplikasi Analisis Multivariate Dengan Program IBM SPSS21. Edisi ketujuh. Badan Penerbit Universitas Diponogero, Semarang.

Handoko, J. (2010). Manajemen Kinerja. Rajawali Pers, Jakarta

Harry, G. and Luis, R. (2016). Managerial Compensation and Firm Performance: A General Research Framework. Academy of Management. e-ISSN 10.5485/251400. Vol. 28, No. 2. Hal. 102-113

Hasibuan, SP. (2014). Manajemen Sumber

Daya Manusia. PT Bumi Aksara, Jakarta

Kadarisman. (2010).

Manajemen

Kompensasi,. Rajawali Pers, Jakarta

Mangkunegara, A. (2011). Daya Ukur Kinerja

Sumber Daya Manusia. Refika Aditama, Bandung.

Milizia, D. (2015). Pengaruh Kompensasi dan Budaya Organisasi PT. Urchaidize Terhadap Kinerja. Jurnal Ekonomi dan Kebijakan. Fakultas Ekonomi Universitas Gunadarma, Bekasi. Volume Jurnal Ekonomi dan Kebijakan. Fakultas Ekonomi Universitas Gunadarma, Bekasi. Volume 14, No.2 Hal. 86-91

Nugroho, E .(2015). Pengaruh Pemberian Kompensasi Terhadap Kinerja Karyawan Bank Mandiri Kota Surabaya. Jurnal Bisnis dan Manajemen, Fakultas Ekonomi 
Universitas Negeri Surabaya. Volume 4 hal. 45-53

Nuswantara, B. (2018). Hubungan Antara Motivasi, Kedisiplinan, Kompensasi, Lingkungan, Dan Peran Supervisor Dengan Kinerja Karyawan Pabrik CV. Cita Nasional di Kabupaten Semarang Jawa Tengah. Garam Kediri. Jurnal Manajemen dan Kewirausahaan. Universitas Diponegoro. ISSN 5482-2458. Vol.3, No. 2. Hal. 35-69

Pearce. J, William B. and James L. (2017).

Managerial Compensation Based on Organizational Performance: A Time Series Analysis of the Effects of Merit Pay. Academy of Management. e-ISSN $10.5465 / 256200$. Vol. 28, No. 2. Hal. 102113

Sagala, D. (2009). Manajemen Sumber Daya Manusia. Ghalia Indonesia, Bogor.

Sanjaya, A. (2015). Evaluasi Kinerja Sumber

Daya Manusia. Salemba Empat, Jakarta

Sari, A. (2016). Peran Mediasi Kepuasan Kerja Pada Pengaruh Kompensasi Terhadap Kinerja Pekerja Kontrak. E-Jurnal Manajemen. ISSN: 2302-8912. Universitas Udayana. Vol. 5, No.1, Hal. 470 - 479

Siswandoko, D, (2011). Manajemen Sumber Daya Manusia Abad 21, Nusantara Consulting, Jakarta

Slamet, A. (2012). "Kompensasi dan Motivasi Pengaruhnya Terhadap Kinerja Karyawan Pada PT.Bangun Wenang Beverages Company Manado". Jurnal Manajemen Operasional. ISSN 2303-1174. Jurnal Emba.Volume 1. Nomor 3. Hal 853- 859

Springer, G. (2016). A Study of Job Motivation, Satisfaction, and Performance among Bank Employees. Journal of Global Business Issues; Burbank. eISSN: 15571211- ISSN: 01492063. Texas Christian University. Vol. 5, Iss. 1, Hal. 2942.

Srimulyani, V. (2013). Pengaruh Motivasi serta Kompensasi Terhadap Kinerja Pegawai
Variabel Pemediasi Kepuasan Kerja Pada PDAM Kota Madiun. Jurnal Riset Manajemen dan Akuntansi. ISSN 23386578. Universitas Katolik Widya Mandala Madiun. Vol.1 No.1. Hal. 7-15

Suwatno dan Priansa, D. (2011). Manajemen Sumber Daya Manusia dalam Organisasi Publik dan Bisnis. Alfabeta, Bandung. Syahyuti. (2010). Definisi, Variabel, Indikator dan Pengukuran dalam Ilmu. Sosial. Penerbit Alfabeta, Bandung

Syamsir. (2013). Organisasi \& Manajemen. Alfabeta, Bandung.

Tampi, B. (2014). Pengaruh Gaya Kepemimpinan dan Motivasi Terhadap Kinerja Karyawan Pada Bank Negara Indonesia tbk Cabang Manado. Jurnal Acta Diurna Komunikasi. ISSN: 2685-6999. Universitas Negeri Manado. Vol.3, No. 2. Hal. 14-19

Wekesa, J.N. (2018). Effect of Compensation on Performance of Public Secondary School Teachers in Eldoret Municipality. International Journal of Scientific and Research Publications. Mount Kenya University. ISSN 2250-3153. Volume 3, Issue 6. Hal 21-35

Wenno, I. (2017). Effect of Principal Managerial Leadership and Compensation towards Physics Teacher Performance in Senior High School in Baguala DistrictAmbon. ERIC Journal. Toronto University. ISSN-1913-9020. Vol.22, No. 2. Hal. 14-20 Werther, B. (2011). Human Resource and Personnel. PT Gramedia Pustaka Utama, Jakarta

Yani. (2012). "Pengaruh Kompensasi dan Motivasi Kerja Terhadap Kinerja Karyawan pada PT. Tunas Hijau Samarinda". Jurnal Manajemen dan Kewirausahaan .Jakarta: P2M Fakultas Ekonomi Universitas Pancasila, Volume 2, Juli, Halaman 14 